\section{ELECTRICITY SUPPLY IN GREAT BRITAIN}

$\mathrm{T}$

WO documents have recently been published on this subject which are likely to have important repercussions in the electricity supply industry of Great Britain. The first of these is a memorandum issued by the Ineorporated Association of Electric Power Companies*, and the second is the report made to the Council of the Institution of Electrical Engineers by its Post-War Planning Committee, on electricity supply, distribution and installation $\dagger$.

\section{Administrative Aspects}

The memorandum issued by the Incorporated Association of Electric Power Companies refers to the progress of, and developments and legislation in, the supply industry, to the Electricity Commission, and to the work and recommendations of the McGowan, Cooper, and Scott Committees. Proposals are then made for the consideration of the Minister of Fuel and Power in respect of (1) electricity distribution, and (2) the Electricity Commission. Their essential features are abstracted in the following.

Electricity Distribution. Improvement should be generally on the lines of the MeGowan Report, subject to the amendments cited later. Legislation should be passed at or before the end of the War to suspend the exercise of the rights of purchase by local authorities and others of any electricity under. taking, but such suspension should not prevent the completion of negotiations for the voluntary acquisition or amalgamation of such undertakings. The Electricity Commissioners should delimit suitable electricity districts and appoint a scheme committee for each district to prepare and submit to the Commissioners a draft scheme for the improvement of distribution in the district in accordance with the terms of the McGowan Report. The scheme committee should consist of representatives of the authorized undertakers in each electricity district. Should the scheme committee fail to prepare or forward a draft scheme for any electricity district, the onus would fall on the Electricity Commissioners.

The Electricity Commissioners should be empowered to make any scheme, but should not make one other than an agreed scheme without holding a local inquiry. The Minister of Fuel and Power should be empowered to confirm any scheme made by the Electricity Commissioners, and any scheme confirmed should be subject to the approval of Parliament. The proposed legislation should prescribe the basis of the purchase price to be paid for the acquisition of any undertaking. Tariff forms throughout Great Britain should be standardized so far as possible. Complete uniformity of charges for the whole country is not economically possible, but may be feasible in an electricity district, and has already been attained in a number of large areas. Retained undertakers should be under an obligation to stan. dardize voltages and systems, as may be determined by the Electricity Commissioners. Legislation should provide in the case of retained undertakers for the

* Memorandum with regard to the Electricity Supply Industry in Great Britain. Pp. 30. (Incorporated Association of Electric Power Companies, 58 Abbey House, Victoria Street, London, S.W.1. 1943.) + Electricity Supply, Distribution and Installation: a Report to the Council of the Institution of Electrical Engineers from the Post war Planning Committee. Pp. ii +26 . (Institution of Electrical Engineers, Savoy Place, Victoria Embankment, London, W.C.2. 1944.) application of an effective sliding scale relating prices to costs and charges, including a reasonable return on capital employed. All retained undertakers should be obliged to submit periodically to the Electricity Commissioners proposals for the develop. ment of the supply of electricity for general domestic purposes, including lighting in any part of their area where there is a demand for such a supply and a prospect of such supply affording reasonable return to the undertakers.

The Electricity Commissioners should appoint a local committee in each area to consult with the retained undertakers on matters affecting development of supplies and prices. The local committee should be representative of local authorities and consumers and should have power to initiate applications to the Electricity Commissioners regarding such matters.

The present system of valuation and rating as affecting the industry has been adversely commented upon by various departmental committees, and it is considered that the whole system should be reviewed. The proposed legislation should include various provisions recommended by the MeGowan Committee on matters such as the procedure for obtaining wayleaves, fixing wayleave rentals and compensation, public supplies of electricity by unauthorized undertakers, and the consolidation of the numerous Electricity Acts into one up-to-date enactment. It is considered that the conclusions of the McGowan Committee and the Cooper Committee and also the views already expressed regarding public corporations and regional boards apply equally to 'public ownership'. If, however, Parliament decides that retained company undertakings should be liable to purchase by some form of public authority, it is considered that the prescribed period should be not less than fifty years and that the option to purchase should be exercisable at the same date for all undertakings. If, at the expiry of fifty years, purchase were not deemed expedient, there should be recurring options at reasonably lengthy intervals.

The Electricity Commission. It is the view of the Incorporated Association of Electric Power Com. panies that the establishment of the Electricity Commission was and is still necessary to the industry. The Minister should have the widest choice in appointing suitable men to the Commission, and the Commissioners, in turn, should be enabled to appoint an experienced and well-paid staff. It is recommended that five Commissioners be appointed at the exrliest possible date and that all the Commissioners, including the chairman, should be men of long and wide experience in the industry. The staff of the Commission should be strengthened and reorganized at the earliest possible date and there should be removed any obligation that its members should be governed by Civil Service conditions and rates of pay. The Electricity Commissioners should have the assistance of an advisory committee to be appointed by the Minister of Fuel and Power after consultation with the electricity supply associations, in regard to the delimitation of electricity districts and other proposals.

\section{Technical Aspects}

The second report, sponsored by the Institution of Electrical Engineers, is confined to technical matters of immediate urgency in connexion with electricity supply, distribution and installation in Great Britain, and it excludes problems of generation and main 
transmission, for which technical policy is already co-ordinated by the Central Electricity Board.

For low-voltage distribution systems, a four-wire, three-phase, $400 / 230$ volt system is the national standard. Its extension throughout Great Britain is recommended as an urgent post-war national industrial plan. Data are given on which a scheme to secure standardization may be based. Complete standardization of all low-voltage distribution systems presents no technical difficulties and could be completed within five years. As the benefit of such voltage standardization mainly accrues to the entire community, it may be the subject of financial discussions with Government, and a detailed estimate has been made of its cost, which amounts to some $\mathfrak{\$ 1 7 . 5}$ millions, based on 1939 conditions and pricelevels.

A brief historical review of the development of urban electricity in Great Britain leads up to the position in 1939 , when of 10.7 million urban dwellings, $\mathbf{7 . 9}$ million were supplied with electricity; among 2.25 million rural dwellings, $1 \cdot 1$ million received a supply, together with at least 35,000 farms. For the completion of rural electrification financial aid will be required for connecting consumers remote from transmission lines, preferably granted for schemes embracing districts as a whole. Wayleave procedure should be simplified and the use of under-eave construction facilitated. Agreement by undertakings on a standard length of underground service cable, laid free, is recommended. A free overhead service line to a total cost not exceeding that of installing the agreed length of underground service cable is suggested. Simplified and less expensive constructions for high-voltage spur lines are proposed, and agreed standards are recommended. Expenditure on such overhead lines must usually be justified by adequate revenue, unless the consumer contributes to first cost or a subsidy is available. Legislation is recommended to bring English law into conformity with Scottish law, which allows a tenant to secure compensation from the landlord for the cost of any wiring installation put in by the tenant. Low-interest loans for wiring, etc., or hire-purchase terms for a ten-year period are advocated.

A report issued in 1930 of a committee set up by the Electricity Commissioners gave a comprehensive picture of the situation at that time and remains largely applicable. The time is appropriate for securing uniformity of tariff forms, and recommendations are made to this end. The merits of the twopart tariff are discussed and recommendations for its wide extension are made. Consumers are classified into the groups domestic, farm, industrial and commercial, and recommendations are made for the equitable assessment of the fixed or primary charge component of the tariffs appropriate to each group. The Electricity Commissioners, it is suggested, should be authorized to permit any undertaking to offer a two-part tariff only, with no alternative flat-rate, subject to certain safeguards to the consumer. Descriptions are given, and the advantages are discussed, of two-part variable-block tariffs, for the above groups, and examples of the working of each are quoted.

Basic changes in the Regulations for the Electrical Equipment of Buildings of the Institution are proposed, leading to their division into Basic Safety Regulations (accompanied by a Code of Practical Interpretation) and supported by Codes of Good Practice to be prepared by the independent Codes of
Practice Committee, set up under the ægis of the Ministry of Works. It is recommended that this very important matter be given early consideration.

No full assessment of the matter of legislative control of the electrical equipment of buildings has been attempted, but an appraisement of the technical aspects of the available evidence does not support a need for the compulsory registration of contractors and operatives or for the exactment at present of compulsory wiring regulations. If necessary, the proposed Basic Safety Regulations could later be given the force of law. Extension of inspection of installations by supply undertakings, more general observance of the wiring regulations, wider use of the voluntary system of registration of installation contractors, insistence on the use of non-kinkable cords for portable apparatus, and the manufacture of accessories and apparatus to extended and specific British standard specifications are recommended.

\section{OPHTHALMOLOGY IN GREAT BRITAIN}

$T$

WE work of the modern ophthalmologist and the tasks he has to face in the future are the subjects of two articles in the British Medical Bulletin (1, No. $9 ; 1913)$. These articles inaugurate a series of outlines of special aspects of British medicine which that journal will publish at irregular intervals in the future.

Discussing the future work of the ophthalmologist, Prof. Arnold Sorsby gives most of his space to blindness, adopting the criterion that blindness means being "so blind as torbe unable to perform any work for which eyesight is essential". He finds that there are at least 100,000 blind people among the population of about 40 million in England and Wales, which is a rate of 2.5 per thousand. It is likely that even now all the blind are not registered by a medical examiner for the benefits obtainable under the Blind Persons Act of 1920 .

In 1910 it was estimated from the census returns of various countries that there were about 3 million totally blind people in the world, but, on the basis of the rate for England and Wales, the world figure would be 5 million. Blindness is, however, much more frequent in India, China and the Middle East than it is in Britain. China alone probably has 4-5 million blind people and India may have almost as many. Prof. Sorsby suggests that there are probably 15 million blind people in the world, and that many millions more have grossly defective sight. Apart from the immediate exciting causes of blindness, the great determining causes are ignorance and poor social and medical services.

The prevention of blindness-surely one of the major tasks of the future-is considered under five hoadings. Among the infective processes causing blindness, ophthalmia neonatorum of the newborn is no longer significant, nor is smallpox now a serious cause of eye disease. Trachoma and the acute ophthalmias of the tropics are not yet controlled. Trachoma probably affects about 15 per cent of the world's population, and its cause is not understood. Possibly a remedy may be found among the sulphonamides. The control of tuberculosis has helped greatly to diminish phlyctenular ophthalmia, the prevalent ophthalmia of childhood, due to tuberculous sensitiza. tion. Advances in public health and hygiene have 